\title{
The Interventions of Pietro da Cortona in the Crypt of Santa Maria in Via Lata in Rome, Studied through a Morphometric Three-Dimensional Survey
}

\author{
Lorenzo Pio Massimo Martino \\ Dipartimento Patrimonio Architettonico Urbanistico, Università degli Studi “Mediterranea” di Reggio Calabria, \\ Via Salita Melissari Feo di Vito, Reggio Calabria, Italy \\ Email: lorenzo.martino@unirc.it
}

Received 18 March 2014; revised 18 April 2014; accepted 25 April 2014

Copyright (C 2014 by author and Scientific Research Publishing Inc. This work is licensed under the Creative Commons Attribution International License (CC BY). http://creativecommons.org/licenses/by/4.0/

(c) (i) Open Access

\begin{abstract}
Twenty years after the last archaeological researches and surveys, a new investigation has been carried out on the basement in the church of Santa Maria in Via Lata in Rome. The study has employed three-dimensional surveys with laser scanning methodology and has focused both on archaeological and architectural issues. Indeed, the present layout of the basement derives from a XVII century remodelling of early Christian and medieval spaces planned by Pietro da Cortona. The architect gave a unique setting and composition to the underground spaces, different in shapes and building materials, thanks to the refinement of his baroque language. Though he worked in small spaces with static problems connected to the foundations and to the loads of the church rising above, and with poor lighting and extreme dampness, Pietro da Cortona put skilfully together "modern" elements with ancient or historical pre-existences. The study focuses on Berrettini's design process through a three-dimensional analysis with CAD systems, starting from the new XVII century façade and from the articulated distribution of routes that led to the intimate underground interiors. Metrical processing gave the possibility to improve the knowledge about room geometry and to confirm the interpretations put forward by major scholars such as Krautheimer and Cavazzi.
\end{abstract}

\section{Keywords}

Laser Scanner 3D, Pietro da Cortona, History of Architecture, Santa Maria in Via Lata, Rome 
The knowledge of an historical architecture is the grounding in any planning process that has to be realized upon it, not least Restoration.

The foundation of this moment of knowing is the historical research backed up by the survey which allows us to understand, "synthesizing" and carefully analyzing, the many-sided information of an ancient architecture. That is, in fact, made of many parts conceived and realized in order to collaborate one with another to hold together the architectonic body which, as well as the human one, moves, dilates, withdraws, according even just to the variations of the thermo-hygrometric conditions of its inside and of the external environment. When one of these parts gets spoiled, the whole suffers the effects. It is self-evident, therefore, the need of critical surveys, regarded as effective measures of documentation and interpretation, indispensable in a Restoration project.

Technological avant-gardes in the field of architectonic survey, such as Laser Scanning 3D systems, reached remarkable goals in terms of acquisition speed and metric accuracy, allowing to import and verify significant data on the "actual" shapes of architectonic apparatus, both on small and large scale, holding the instrument of the "survey" as an objective source of knowledge.

If the search for information is the foundation of the History of Architecture, a rigorous survey-allowing the acquisition of objective data, as in an instrumental three-dimensional "modern" architectonic survey-is today, in addition to traditional written sources, a fundamental instrument for the knowledge o fan architectonic construction. This kind of documentation can represent one of the most important "written" sources, especially when the archival documentary evidences are scarce, if not absent.

This enables us to deeply penetrate the physicality of the constructed, going beyond a simple natural observation. With the help of three-dimensional survey we can detect particulars which are unlikely perceivable through natural observation or the reading of photographic images, analysis on the details and on the building techniques.

In the case of building hardly readable because of a not perfect state of conservation, the computerized three-dimensional technique can improve the readability suggesting a completion of the shape, through virtual operations of anastylosis or simple restitching of the parts without any physical intervention on the object.

The new survey techniques allow the historian of architecture to "read again" architectonic works with the aid of original figurative data, dimensional and structural, supporting knowledge so much as other modern technologies applied in the field of History of Art (fluorescence, infrareds, radiographies etc..) which enable to study the texture and the phases of a painting or the chemical composition of its colours, penetrating its essence.

In the years 1658-1661 Pietro da Cortona realized an intervention in some underground rooms of the crypt located in the Church of Santa Maria in Via Lata in Figure 1, within a conscious plan — which has not been taken into account by the architectonic criticism until now [1]—in which the artist's own language merges with a scenery referable to the most ancient history of the site [2]. In the early 20th century the archaeologists who studied the area, showing a little interest in the most "recent" stage of the structures, have unconsciously contributed to the loss of the correct readability of the architect's project in the hypogean area, marginalizing it with respect to the interventions at the church level. The symbolic value of the place, see of the first cardinal deaconship which—according to the tradition—had hosted St. Paul in chains, suggests Pietro da Cortona a new fruition of the underground rooms through the adoption of solutions that hold a tight relation with the pre-existences, which the artist acknowledges as intrinsic "values" of the crypt. In the underground areas excavated between 1904 and 1914 by Luigi Cavazzi [3]—who first unearthed the Roman structures—Richard Krautheimer [4] recognized a large portico laid down on four parallel rows of travertine pillars (of which only four are visible today), with a nave twice as long as the aisles and about 10 meters high, which was built in the 1st century, but radically restructured in the 3rd century fractionalizing the areas, even on more levels, with brickworks that constitute the walls of the crypt's rooms which is to host the first cardinal deaconship in Figure 2. The spaces, probably endowed with mezzanines in accordance with the presence of brackets suited to support a wooden truss, are functional to hosting goods or to being opened on the street for trade purpose. So the building proves to be well integrated in the housing and trade landscape —-made by many-levels insulae, large horreas and service buildings - which develops during the Emperor Adriano's age in the proximity of the first stretch of via Flaminia. The three-dimensional survey permitted the complex representation of the site-heterogeneous in the materials used, composed by various areas on different height levels, modified during the time-allowing to realize views which enable an easy "reading" of the components of the underground complex in their whole in 


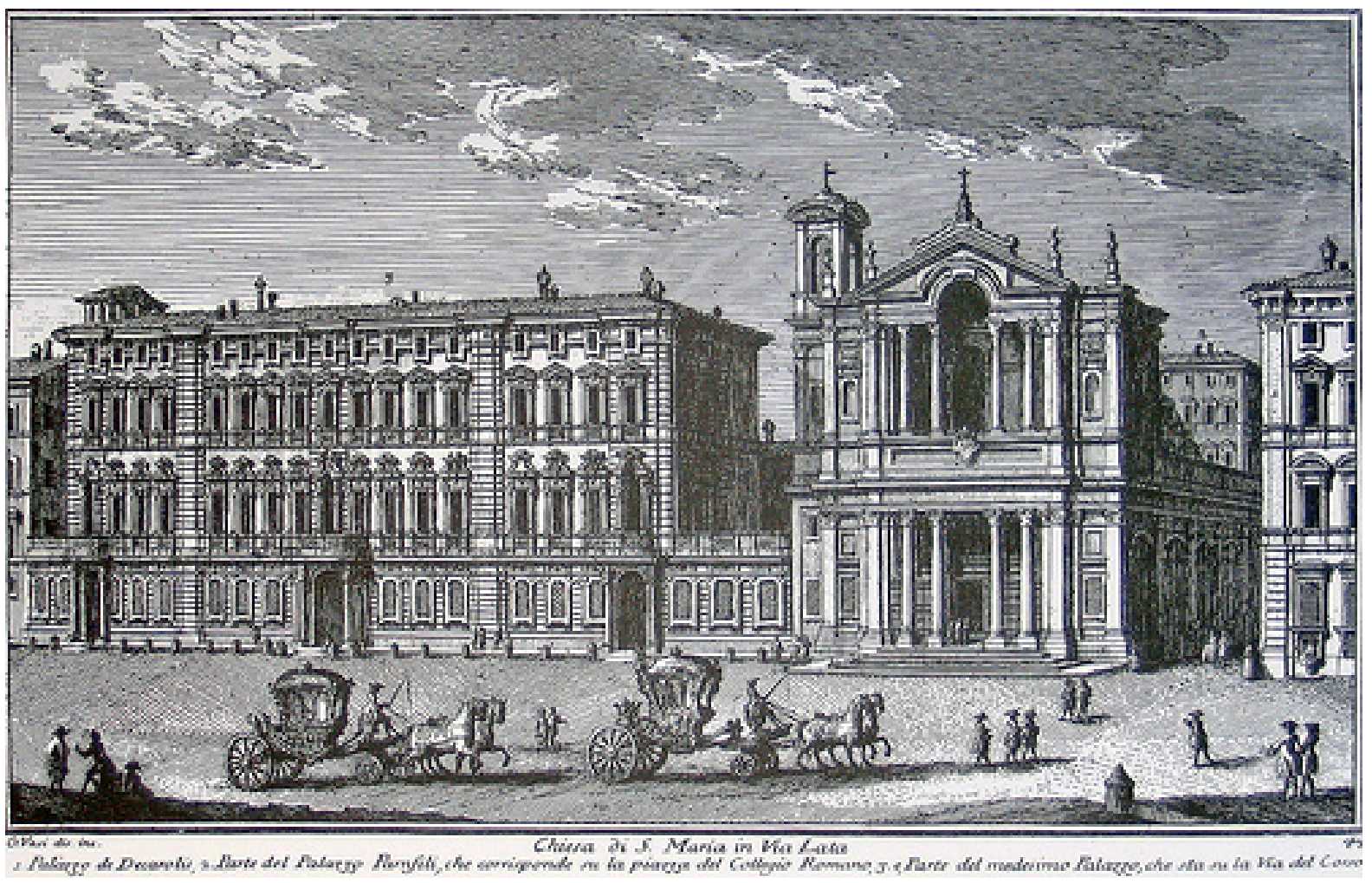

Figure 1. Rome. S. Maria in Via Lata.

Figure 3, the different levels of the various areas and their interconnections in Figure 4; to verify the spaces pertaining to the church in relation to those pertaining to the adjacent Doria Pamphilj palace and finally to carry out a digital comparison between the new surveys and those performed by Cavazzi in Figure 5 and Krautheimer in Figure 6.

The numbering of the rooms has maintained the sequence assigned by Krautheimer with the inclusion of room VII, subsequently unearthed in Figure 4. The derived reading allowed to identify the contribution given by Pietro da Cortona in re-planning some spaces which were destined to a new fruition of the crypt, such as the new entry stairs from the church which, once at the hypogean level, allow an immediate perception of the new altar dominated by the huge marble bass-relief by Cosimo Fancelli in room V. The works planned in the Church of Santa Maria in Via Lata, begun in 1658, rank around the end of Pietro da Cortona's career. The experience matured by the artist, allows him to apply now daring solutions - with the awareness that each element should have been put in relation with the underlying structures - in the new façade of the church, in the spectacular forceps-shaped entrance hall, with the insertions that lead from the hall itself to the crypt suggesting, through refined solutions, scenographic effect of great impact. Planning the new façade, Pietro da Cortona sets pseudo-Corinthian pilasters on the laterals, advancing the façade's line towards the centre, where four columns support the trabeation of the first order. On the second floor, the orders shorten because of the presence of an high attic and they hold a mixtilinear gable-topped architrave, while the central columns make a "serlian". The dynamism expressed in the central part of the façade reaches its climax inside the atrium, where the architect conceives of a space pseudo elliptic, covered by a lacunar vault which widely expands on the sides. From here originate the accesses to the crypt's chambers, on the shorter sides of the ellipse, with a L-shaped path which leads to the most intimate part of the whole project. Before this intervention, the only access to the subterranean was granted by a stair getting down to room I. The only accessible areas were room I, where there were an altar and the well, and room II, with an ancient altar, plugged old openings and the wall which had hidden the apse half-dome. With the exception of the altar in room I, all these elements are still present. Near the well, a big sheet was used to put the glasses to drink the water, regarded as miraculous. Along the eastern side of these two rooms, Pietro da Cortona will set up some wolf's mouths in order to mitigate the problems of excessive humidity, problems which are still findable today and 


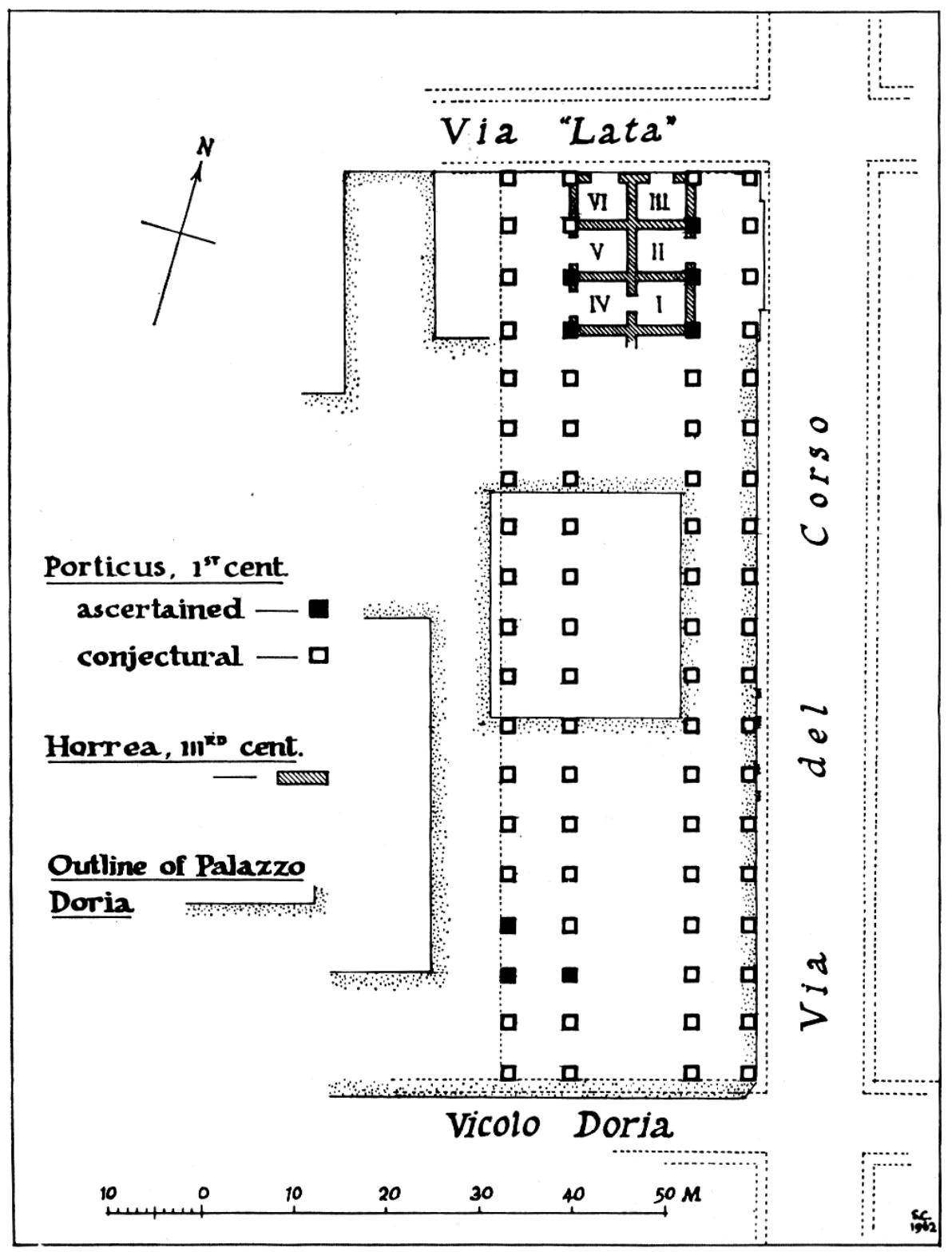

Figure 2. Plan of the porticus under the Palazzo Doria Panphilj (KRAUTHEIMERCORBETT-FRANKL 1971).

which were highlighted in the early 17th century by Fioravante Martinelli who remembers the image of an ancient Madonna translated into the upper church and the damaged paintings covering the walls; today only some fragment remains of different epochs' frescoes. The works made to realize the new stairs disclosed room III; the opening in the room II, earlier apsidal, attained with the removal of the tophus block in the western wall (reinforced with a brick archivolt), enables Pietro da Cortona to go deeper toward the overhanging church and to open the sight of room $\mathrm{V}$, regarded as the ideal stage wing showing itself to the sight, going down from the two staircases. The study of the visual perceptions emerges as the occasion to verify the high qualitative-planning level of the intervention. The trajectory of an optic cone, embracing the whole composition sighting the walls freed by the tophus blocks, directs toward the altar as soon as one got down from the stairs, in the center of room II.

The optic cone in Figure 7 allows to observe, with a single glance (today disturbed by the presence of an iron gate), the whole sculptural-architectonical composition of the bottom wall of room V, where Pietro da Cortona puts a marble altar, crowned by a bass-relief in Figure 8. 


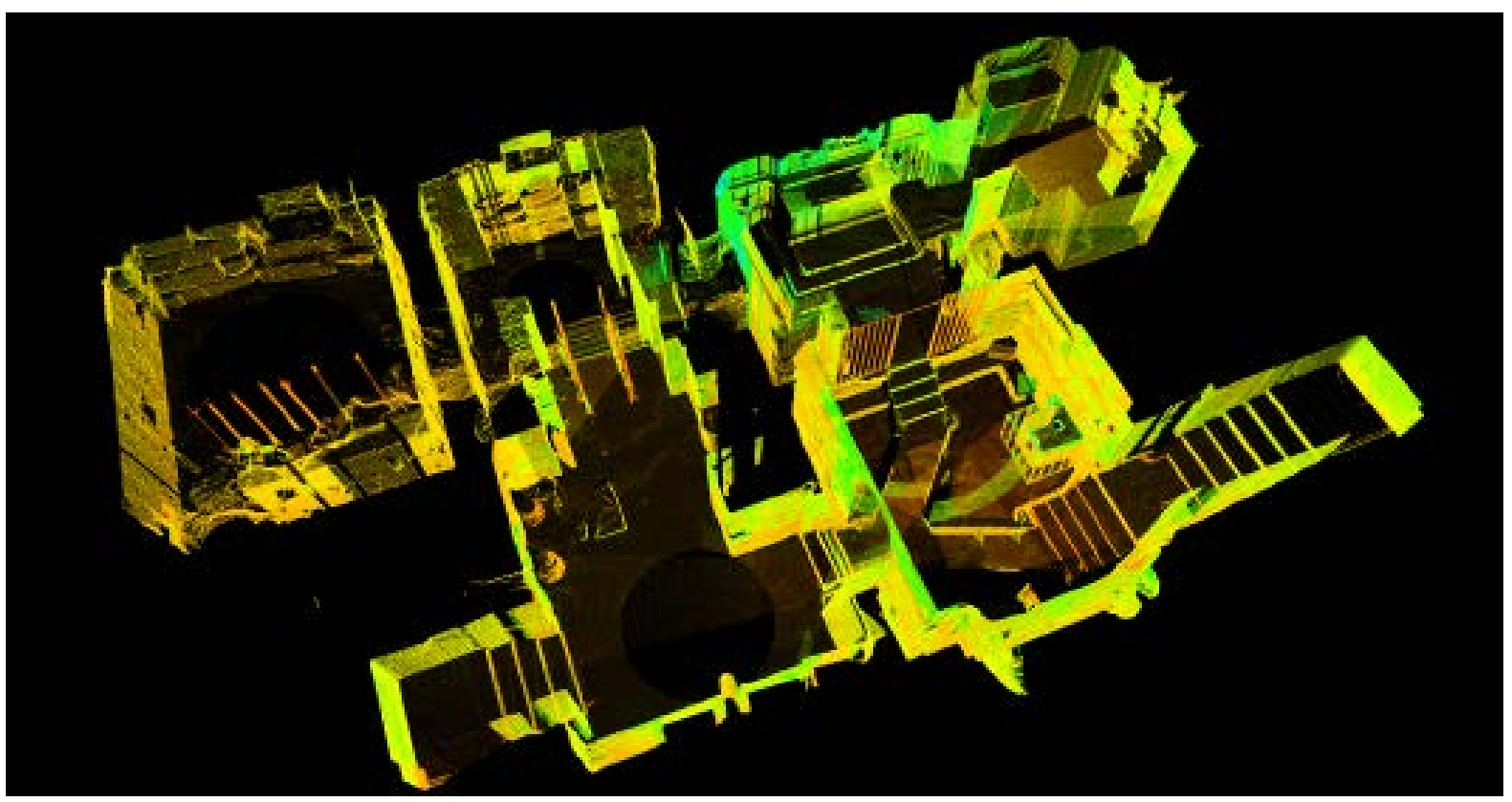

Figure 3. Three-dimensional view, a bird’s eye from the Crypt in the basilica of Santa Maria in Via Lata.

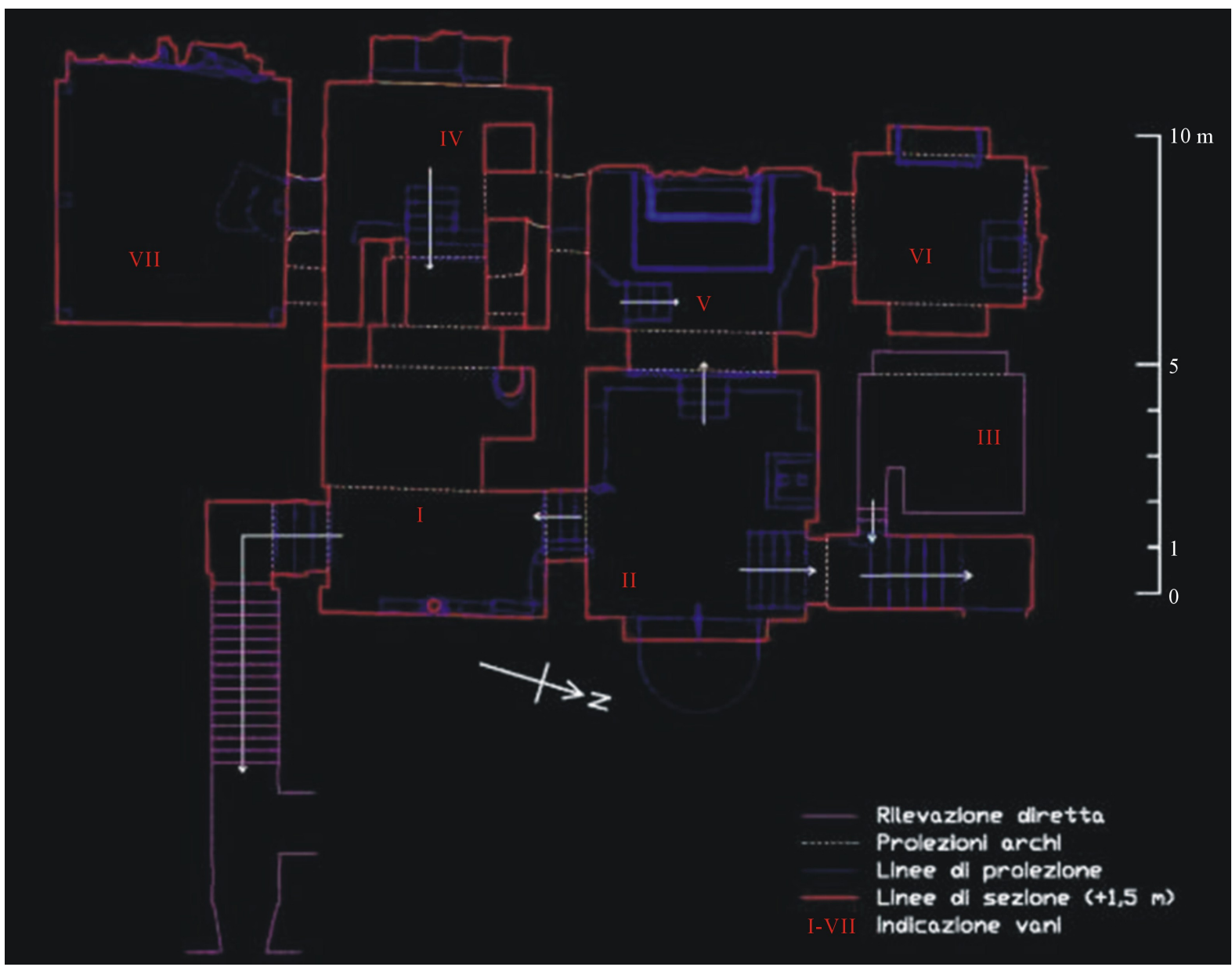

Figure 4. Plan of the crypt in the basilica of Santa Maria in Via Lata. 


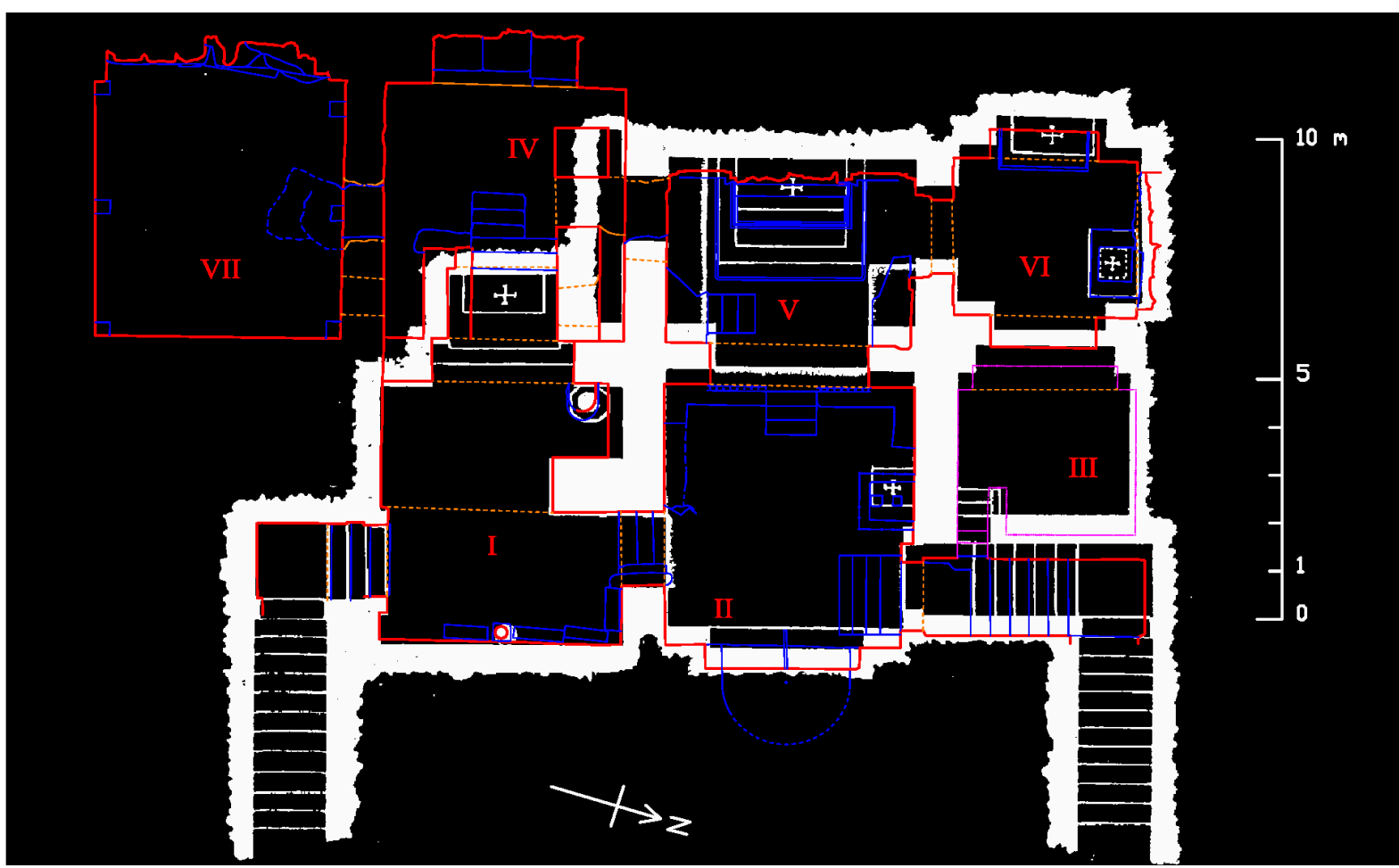

Figure 5. Digital overlay of the crypt in the basilica of Santa Maria in Via Lata detected three-dimensionally (in red section, projections in blue) with graphs of planimetric Richard Krautheimer (in white), from CAVAZZI 1908.

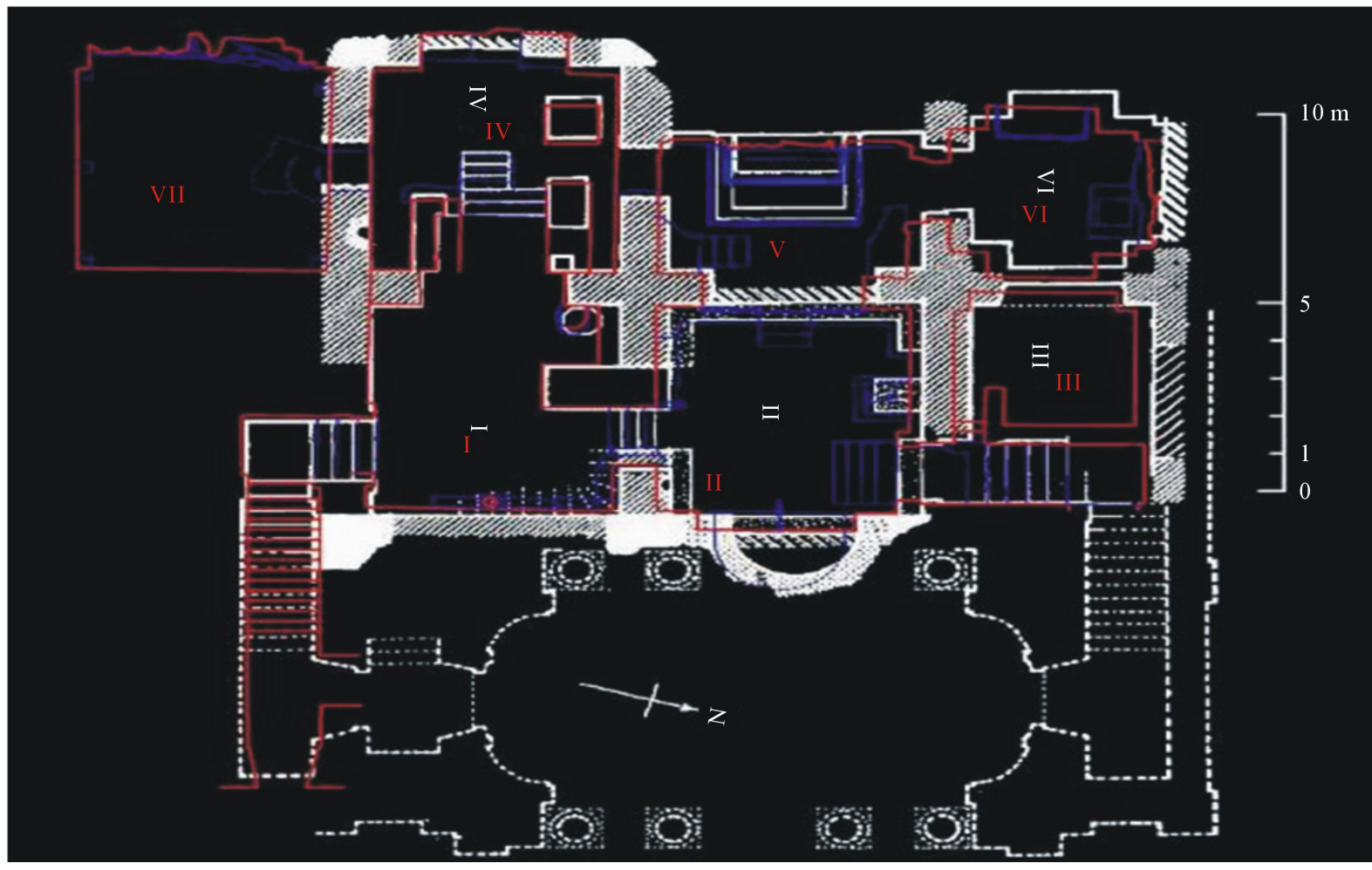

Figure 6. Digital overlay of the crypt in the basilica of Santa Maria in Via Lata detected three-dimensionally (in red section, projections in blue) with graphs of planimetric Richard Krautheimer (in white), from KRAUTHEIMER-CORBETTFRANKL 1971. 


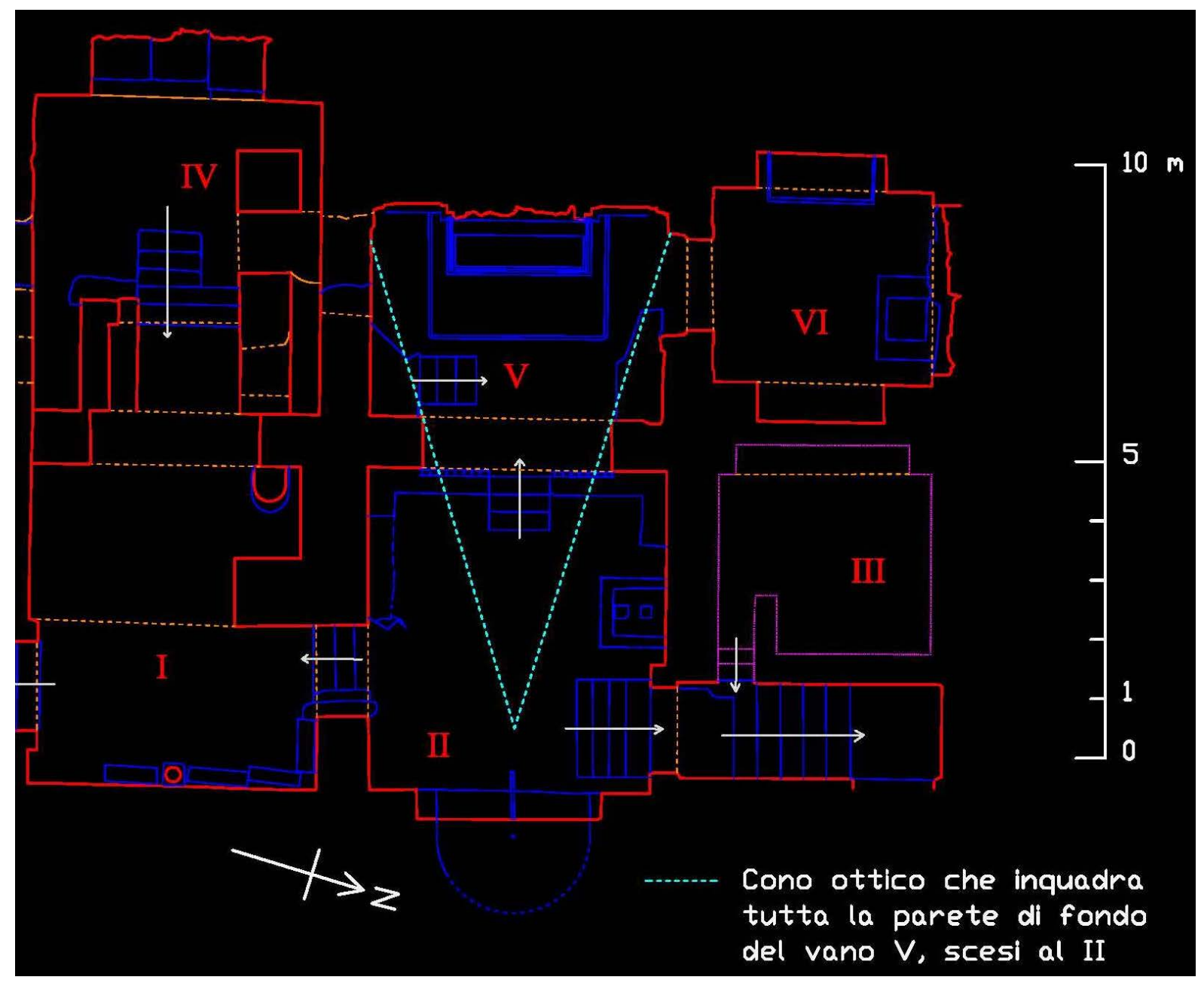

Figure 7. The optical cone (blue dashed line) can be observed, with a single glance, the whole composition sculptural-architectural compartment II to the back wall of the room V.

The bass-relief, a work by Cosimo Fancelli [5], represents Saint Paul on the left, Saint Peter in the middle, in the background and just hinted, Saint Luke, and on the right, in the high relief, Saint Martial. The tradition hands down that it was the latter to build the first oratory in the place inhabited also by Saint Peter and Saint Luke-here he also painted his first image of the Madonna - and from where Peter and Paul were led to Mamertimo prison before their martyrdom [6].

The marble altar piece with the saints is located in an elegant beaded frame, tangent the vault and jutting in the centre, in correspondence to a truss; the background frame underlines the geometries of the vaulted cover, connecting on the wall with the panels, which host small planes supported by truss which, on a back plane, drawn on the profiles of the altar's plane. The altar-cloth, put on two stairs, shows a polychrome decoration in marbled squares, with a Clypeus containing a rostral cross at the centre. On the right there is the passage to the adjacent chapel (room VI), whose area, including the refined crossing cover in Figure 9, is completely plastered and daubed, with the exception of the background wall at the entrance where there is a wall (delimited by a simple frame) with huge blocks "out-of-scale" respect to the dimension of the space in Figure 10. Adjacent to these blocks, there is an old altar with a Cosmatesque covering and with a decentralized position; probably Pietro da Cortona wanted to reallocate in situ this pre-existence in the place of permanent sacredness over the centuries.

The elegant pavement of the room, in brick elements, continues under the heavy blocks and this seems to suggest that Pietro da Cortona himself recomposed them, probably recovering the blocks from those ones removed from the wall between room II and V. Even the opening of a big window, strongly splayed over the wall, seems to show that the stone-blocks wall is a scenographic intervention of the architect that emphasizes the "roman spirit", 


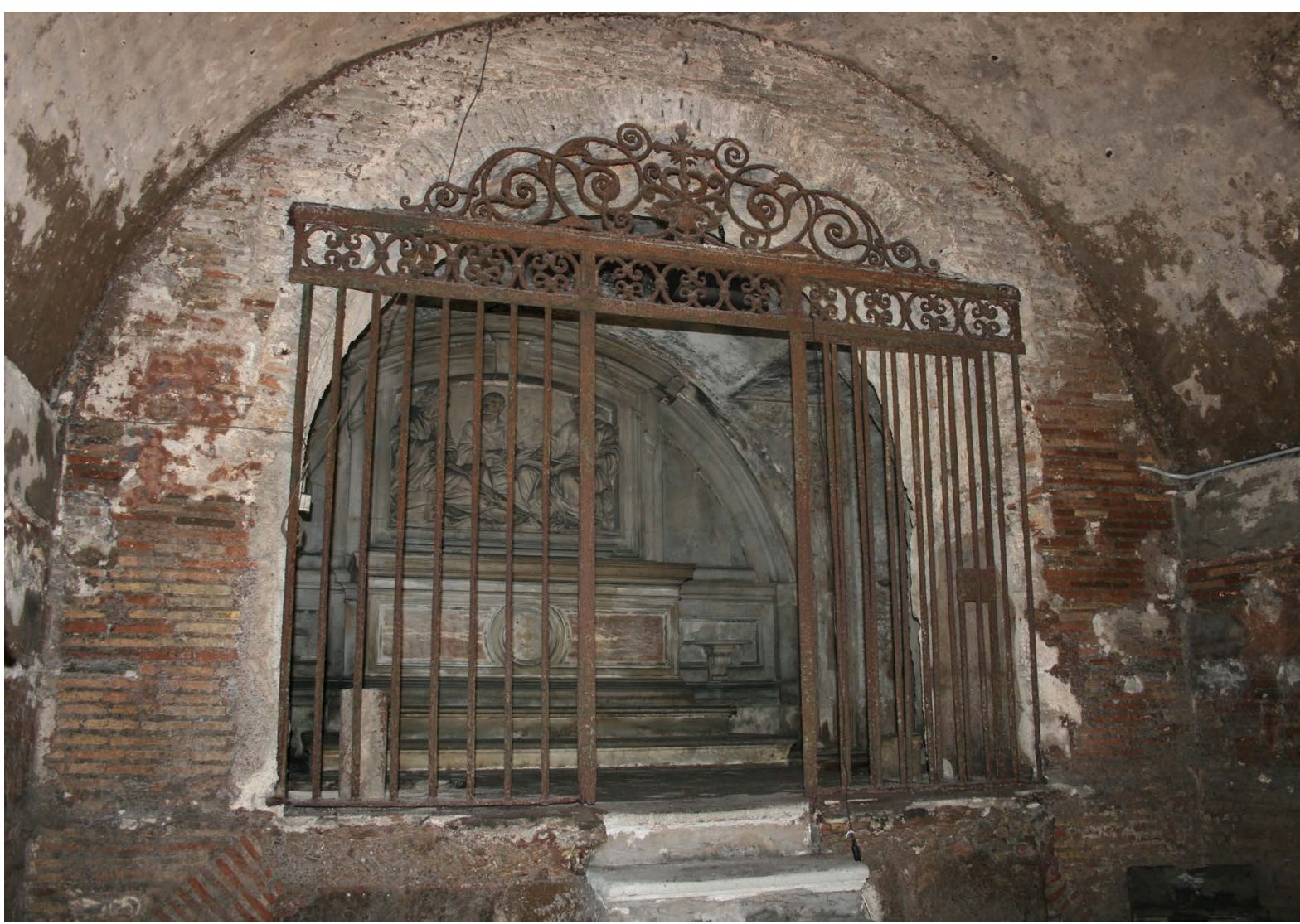

Figure 8. The bass-relief by cosimo fancelli in the v compartment.

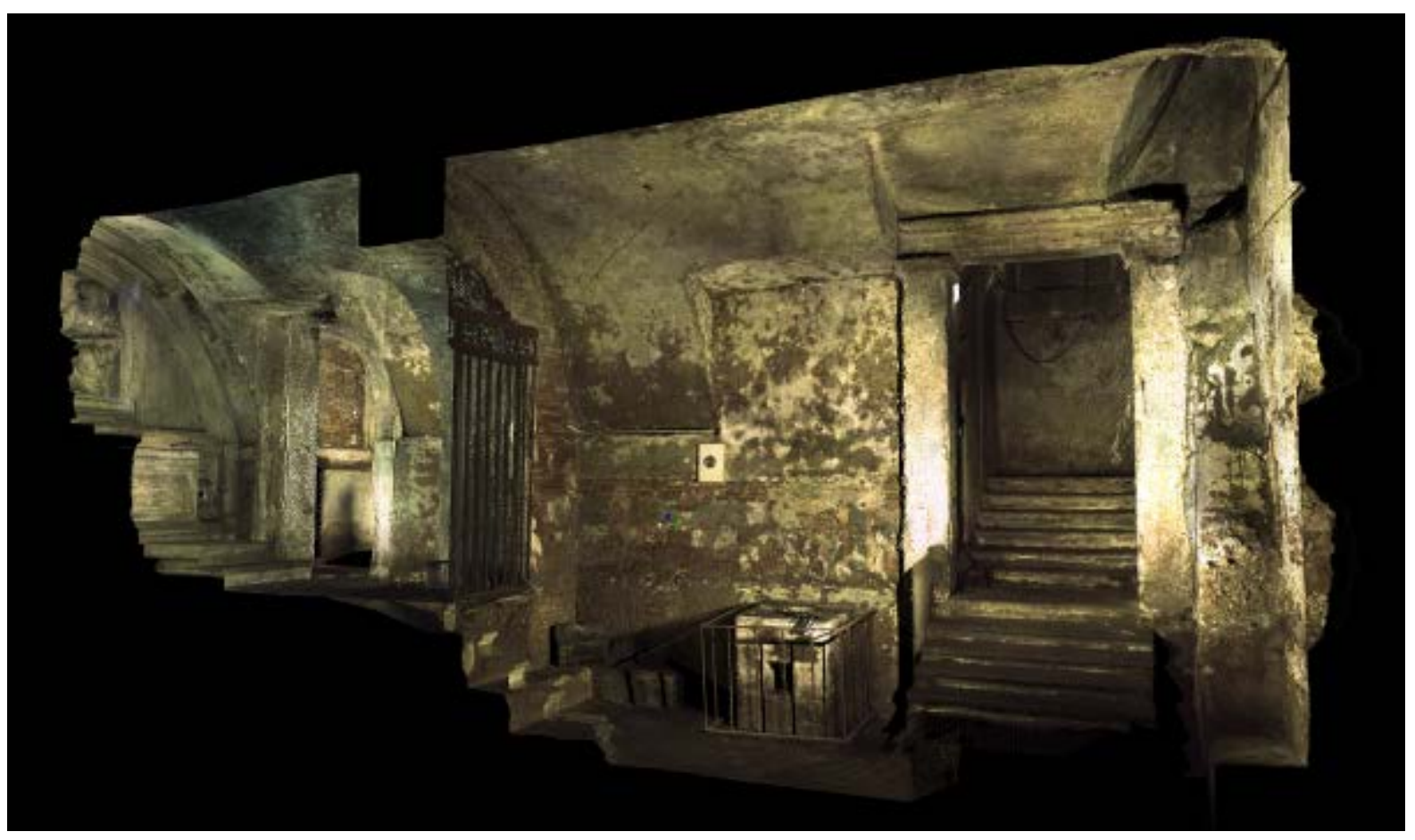

Figure 9. V and II compartment, the crypt of the Basilica of Santa Maria in Via Lata, Rome. Model three-dimensional perspective section. 


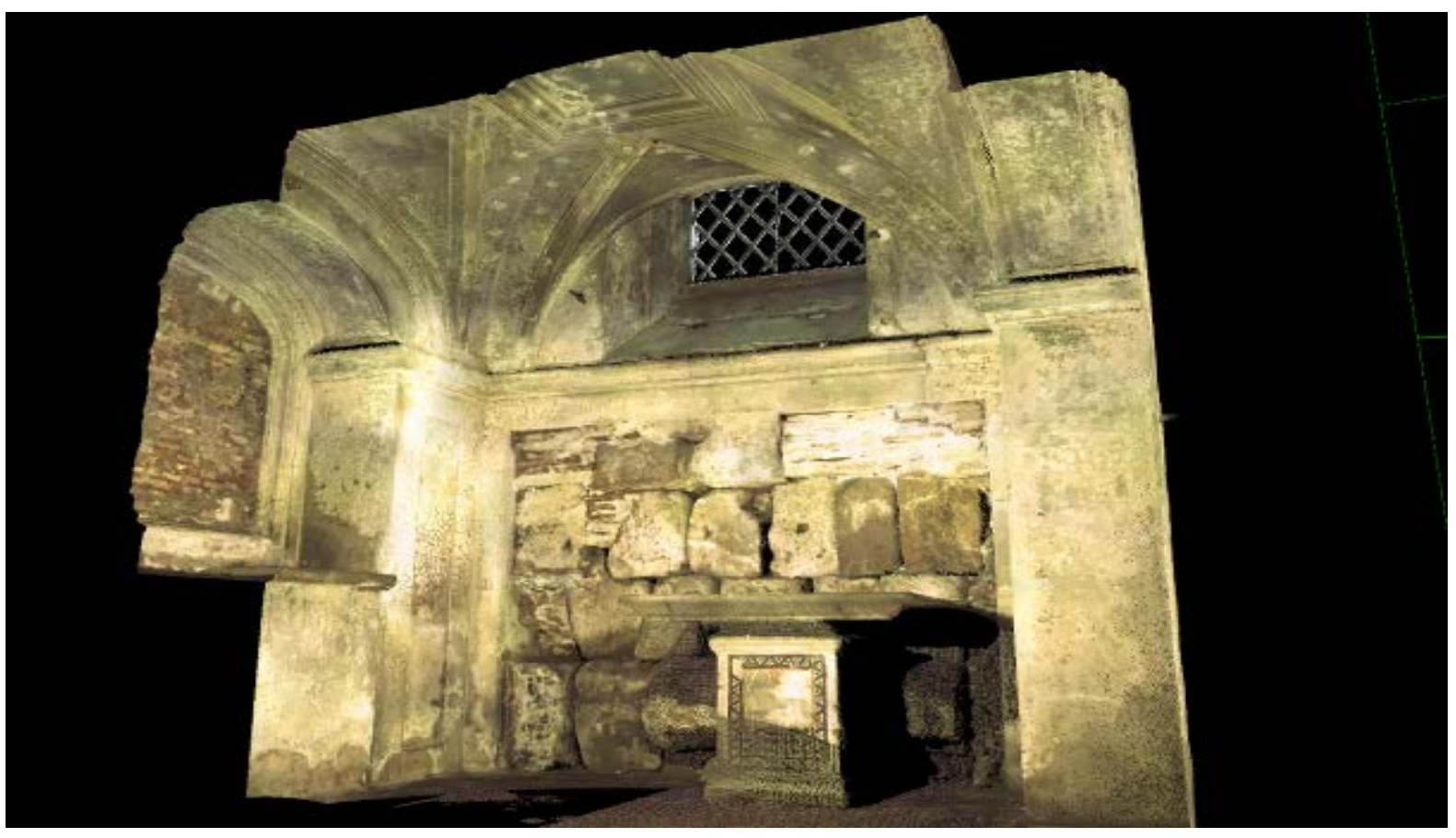

Figure 10. VI compartment, the crypt of the Basilica of Santa Maria in Via Lata, Rome. Model three-dimensional perspective section.

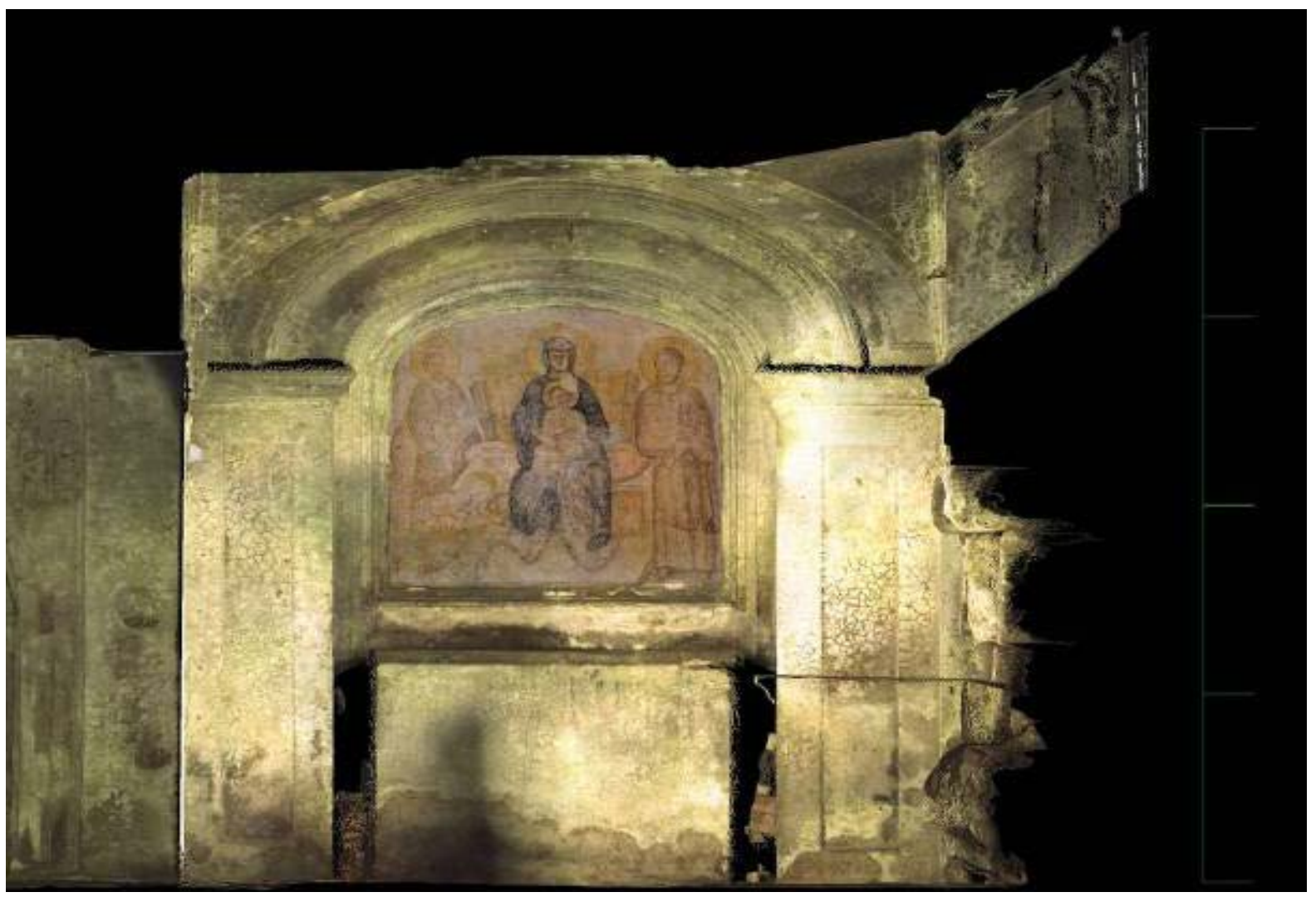

Figure 11. Compartment VI, elevation of the west wall with the relocation in digital overlay of the fresco with the Madonna and Child with Saints Peter and Paul, now in the National Museum of Balbi's Crypta, in the crypt of the Basilica of Santa Maria in Via Lata, Rome 
using it as a stage wing, framed by stripes of plaster, with above beaded frames which follow horizontally the north-south fronts, deviating theirs rectilinear course to support the entrance door, almost wishing to highlight their own respect for those "excellent" pre-existences.

Even if the kind of decoration and the general setting of the rooms are linked to what had been planned for the more elaborate crypt of the Saints Luke and Martina's Church in Rome, Pietro da Cortona in this work writes one of the most beautiful pages within a planning in the "built". His intervention, in fact, proves to be discreet and functional in relation to the strong historic weight of the pre-existences, which he doesn't fail to confirm through the elegance of his baroque language, setting up on the northern wall of room VI an original scenographic composition which completes itself in the western wall fresco-regarded as executed by the same baroque artist, according to the model of a previous medieval fresco with the Madonna and Bambino and the Saints Peter and Paul—virtually reallocated in its initial position in this study in Figure 11.

\section{References}

[1] Pierdominici, M.C. (2010) La Chiesa di Santa Maria in Via Lata—Note di storia e di restauro. Gangemi, Roma.

[2] Martino, L.P.M. (2009) Architetture. Forma ed essenza. Argos, Roma.

[3] Cavazzi, L. (1908) L'oratorio sotterraneo della Via Lata e le recenti scoperte. In: Id. La Diaconia di Santa Maria in Via Lata e il Monastero di S. Ciriaco. Memorie Storiche, Federico Pusted, Roma

[4] Krautheimer, R., Corbett, S. and Frankl, W. (1971) Corpus Basilicarum Christianarum Romae. PIAC-Pontificio Istituto di Archeologia Cristiana, Città del Vaticano

[5] Wittkower, R. (1993) Arte e architettura in Italia (1600-1750). Einaudi, Torino.

[6] Moroni, G. (1842) Dizionario di erudizione storico-ecclesiastica. Tipografia Emiliana, Venezia. 
Scientific Research Publishing (SCIRP) is one of the largest Open Access journal publishers. It is currently publishing more than 200 open access, online, peer-reviewed journals covering a wide range of academic disciplines. SCIRP serves the worldwide academic communities and contributes to the progress and application of science with its publication.

Other selected journals from SCIRP are listed as below. Submit your manuscript to us via either submit@scirp.org or Online Submission Portal.
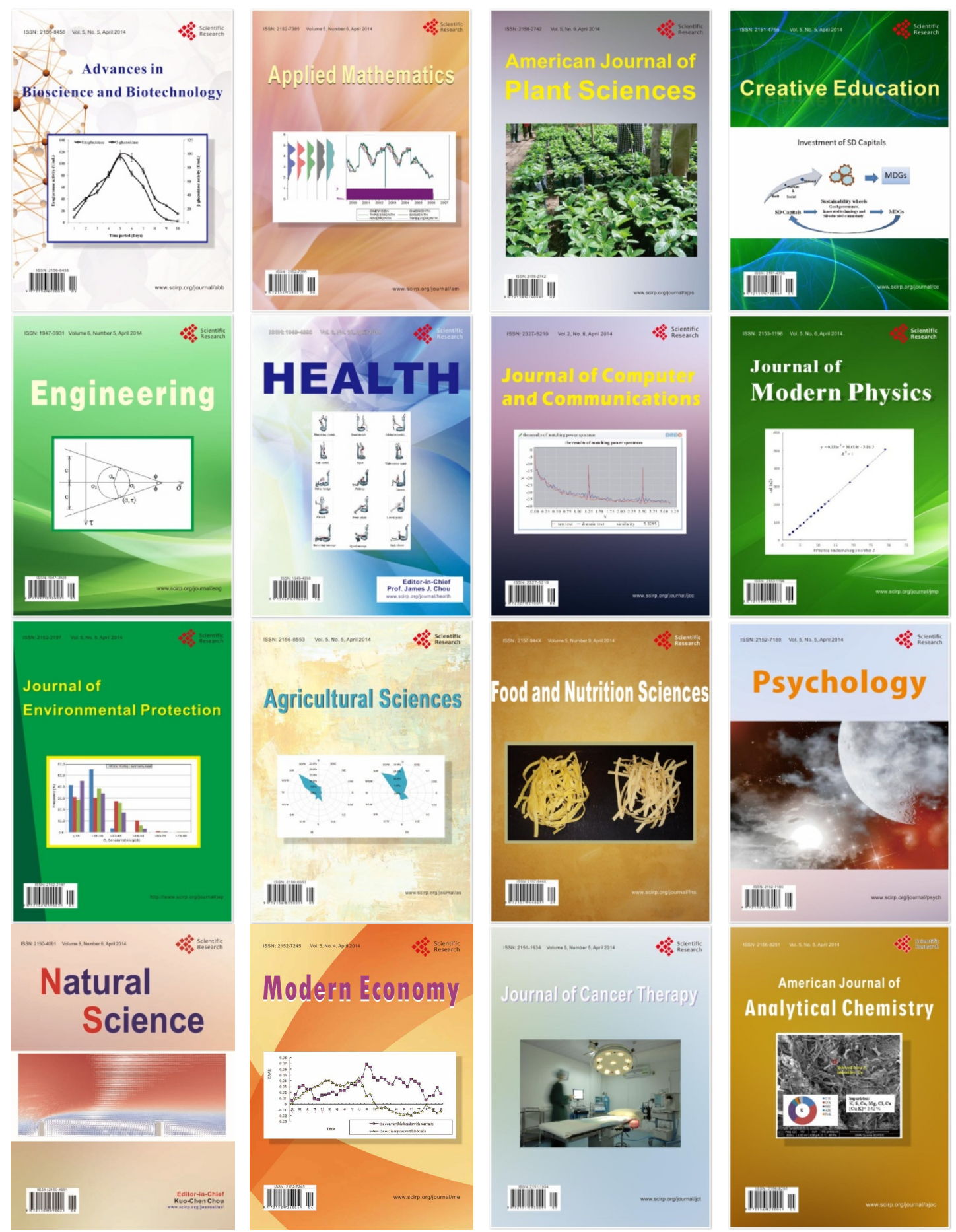